\title{
Determination of Economic Injury and Threshold Level of Maruca vitrata (Geyer) in Green Gram
}

\author{
H. C. Patel ${ }^{1 *}$, P. K. Borad ${ }^{2}$ and N. B. Patel ${ }^{3}$ \\ ${ }^{1}$ College of Agriculture, Anand Agricultural University, Vaso (Gujarat), India \\ ${ }^{2}$ Department of Entomology, B. A. College of Agriculture, Anand Agricultural University, \\ Anand (Gujarat), India \\ ${ }^{3}$ AICRP on Biological Control of Crop Pests, Anand Agricultural University, Anand \\ (Gujarat), India \\ *Corresponding author
}

\section{A B S T R A C T}

\section{Keywords}

Maruca vitrata,

Economic Injury

Level, Economic

Threshold Level,

Green gram

Article Info

Accepted:

20 August 2020

Available Online:

10 September 2020
In order to assess Maruca vitrata (Geyer) damage in green gram and the initiation of control measure with the concept of economic injury level, the experiment was carried out during kharif season of 2012 and 2013 at Anand Agricultural University, Anand. The investigation on Economic Injury Level (EIL) of $M$. vitrata was determined as 0.83 and 0.71 larva per meter row, while Economic Threshold Level (ETL) were found 0.62 and 0.53 larva per meter row during first and second year, respectively. On the basis of mean of two years, the EIL and ETL values of $M$. vitrata were 0.77 and 0.58 larva per meter row (i.e. ETL $\approx 1$ larva/2-meter row) in green gram, respectively.

\section{Introduction}

Green gram, Vigna radiata (Linnaeus) Wilczek is grown in an area of 1.29 lakh ha, producing 0.61 lakh tonnes with an average productivity of $473 \mathrm{~kg} / \mathrm{ha}$ in Gujarat (Anonymous, 2015). The productivity of green gram has rather remained static due to insect pests which cause yield losses both quantitatively and qualitatively. Of the insect pests attacking green gram, Maruca vitrata (Geyer) is the most destructive and major pest as it causes 20 to 40 per cent pod damage (Bindra, 1968and Rahman, 1998). In past decades, unreasoned or systematic (calendar spraying) chemical control has been progressively replaced by integrated pest management (IPM) programmes in India, although in the most cropping situations chemical control remains the chief tool to achieve successful control of insect pests. Implementation of reliable economic-injury levels (EILs) and economic thresholds (ETs) for decision-making in IPM programmes leading to reduced insecticide sprayings is a crucial task, which will not only minimise chemical residues and environmental impact but also will doubtless improve the biological 
control exerted by native larval parasitoids (King and Coleman, 1989 and Torres-Vila et $a l ., 2000)$.Keeping this in view, the present study was conducted for determination of economic injury and threshold level of $M$. vitrata in green gram.

\section{Materials and Methods}

For evaluating Economic Injury Level of $M$. vitrata in green gram, the experiment was conducted at College Agronomy farm, B. A. College of Agriculture, Anand Agricultural University, Anand (Gujarat) during kharif seasons of 2012 and 2013by adopting method ofZahid et al., (2008). The method of artificial infestation by different levels of larval population was followed to establish the economic injury level of $M$. vitrata. There were six treatments consisted of six different larval density i.e. 0, 1, 2, 3, 4 and 5 larva(e) per meter $(\mathrm{m})$ row length, released at flowering stage of the crop. The EIL was determined based on the benefit cost ratio as suggested by Farrington (1977).

Seeds were sown in one-meter length row at $15 \mathrm{~cm}$ distance. The experiment was laid out in Randomized Block Design and replicated three times. The plants of one-meter row length were covered with nylon mesh cages of $1.0 \times 0.5 \times 1.0 \mathrm{~m}$ size before flowering to avoid natural infestation. The cages were designed in such a way that they did not interrupt ventilation and aeration to the growing plants inside. The bottom edges of the cages were inserting into the soil in all sides to check the escape or entry of larvae. These nylon net cages were erected on bamboo sticks fixed in four corners. The second or third instar larvae were released once at the time of flowering and subsequently at 10 days interval to maintain constant population till the maturity stage of the pod. Pupal and prepupal stages of larvae from the previous release was collected at the time of next release.
The number of total and damaged pods and weight of grains from all the covered plants of each cages were recorded. The relationship between larval density and percentage of pod damage was worked out by correlation coefficient and regression equations. The yield data was converted into $\mathrm{kg} / \mathrm{ha}$. Yield losses due to different treatments were derived by deducting the yield of respective treatment from the yield of control (where no larvae were released). The value of yield loss was determined according to the wholesale market price of green gram grains prevailing at Anand just after harvest during the season. Eighty per cent of yield loss considered to be avoided with insecticidal treatment, hence it was taken as avoidable loss or yield saved. Benefit cost ratio (BCR) was worked out as the ratio of the value of yield saved to the cost of insecticidal application. Emamectin Benzoate 5 WG @ 0.0015 per cent (3 g/10 litre of water) was considering for calculating the cost of insecticidal application. Finally, the economic injury level for pod borer larva(e) was calculated by fitting regression equation $\mathrm{Y}=\mathrm{a}+\mathrm{bX}$, between larval population level and benefit cost ratio. The larval density corresponding to unit benefit cost ratio at 1.1 was the economic injury level and economic threshold level was set at 75 per cent of EIL (Pedigo, 1991).

\section{Results and Discussion}

\section{Pod damage and grain yield}

The variation in numbers of pods per plant in different six $M$. vitrata larval density treatments were found non-significant (Table 1). Pod damage due to $M$. vitrata was increased with increasing in larval density by observing 9.83 (1 larva/meter row) to 34.21 per cent (5 larvae/meter row) and 10.32 (1 larva/meter row) to 36.77 per $\operatorname{cent}(5$ larvae/meter row) during the year 2012 and 2013, respectively. The grain yield per plant 
varied from 5.24 to 9.00 gram in first and 5.62 to 10.05 gram in second year corresponding to larval density of five to zero per meter row length. In case of per cent yield loss due to $M$. vitrata with respect to no larval population, it was lied between 11.05 and 41.79 in first year, while during second year it was observed between 14.10 and 44.06 per cent with one to five larval density per meter row (Table 1). Moreover, correlation coefficient between larval density and per cent pod damage showed highly significant positive relationship during first $(\mathrm{r}=0.996 * *)$ and second $\left(\mathrm{r}=0.988^{* *}\right)$ year of study.

\section{Economics}

By considering eighty per cent yield loss saved with emamectin benzoate 5 WG @ 0.0015 per cent and cost of insecticide application, benefit cost ratio (BCR) were 1: 1.49, 1: 2.13, 1: 3.94, 1: 4.94 and 1: 5.61 during 2012, while 1: 1.70, 1: 2.81, 1: 4.10, 1: 4.78 and 1: 6.61 during 2013 (Table 2) at 1, 2, 3,4 and 5 larva(e) per meter row, respectively.Zahid et al., (2008) stated that ratio of the value of yield saved to the cost of insecticide application at one larva of $M$. vitrata per meter row was 1.34 to 1.45 in green gram.

\section{Economic Injury Level of $M$. vitrata}

The determination of economic injury level for pod borer larva(e) was calculated by fitting regression equation $\mathrm{Y}=\mathrm{a}+\mathrm{bX}$, between larval population levels and benefit cost ratio. There was a highly significant positive correlation and linear relationship between larval densities and BCR (Fig. 1). Economic injury level lies at the pest population density where BCR would be 1.1. In order to calculate the exact density at which BCR would be 1.1 the correlation of larval density $(\mathrm{X})$ with the $\mathrm{BCR}(\mathrm{Y})$ was calculated. The regression equations derived as under.

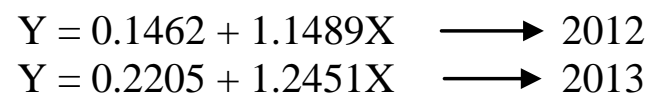

From the above regression equations, the economic injury level of $M$. vitrata larva determined as 0.83 and 0.71 larva per meter row of green gram during 2012 and 2013, respectively (Fig. 1). On the basis of means of two years, the economic injury value was 0.77 larva per meter row in green gram. Zahid et al., (2008) determined that the EIL of $M$. vitrata was 1.08 larvae per meter row in green gram.

Table.1 Effect of larval density of $M$. vitrata on pod damage and yield loss in green gram

\begin{tabular}{|c|c|c|c|c|c|c|c|c|}
\hline \multirow{2}{*}{$\begin{array}{c}\text { Larval } \\
\text { density/ } \\
\text { meter row }\end{array}$} & \multicolumn{2}{|c|}{ Pods/plant } & \multicolumn{2}{c|}{$\begin{array}{c}\text { Pod damage } \\
(\mathbf{\%})\end{array}$} & \multicolumn{2}{c|}{$\begin{array}{c}\text { Yield/plant } \\
(\mathbf{g})\end{array}$} & \multicolumn{2}{c|}{$\begin{array}{c}\text { Yield loss } \\
(\mathbf{\%})\end{array}$} \\
\hline $\mathbf{0}$ & $\mathbf{2 0 1 2}$ & $\mathbf{2 0 1 3}$ & $\mathbf{2 0 1 2}$ & $\mathbf{2 0 1 3}$ & $\mathbf{2 0 1 2}$ & $\mathbf{2 0 1 3}$ & $\mathbf{2 0 1 2}$ & $\mathbf{2 0 1 3}$ \\
\hline $\mathbf{1}$ & 19.00 & 19.68 & 0.00 & 0.00 & 9.00 & 10.05 & - & - \\
\hline $\mathbf{2}$ & 18.94 & 19.16 & 9.83 & 10.32 & 8.00 & 8.91 & 11.05 & 11.35 \\
\hline $\mathbf{3}$ & 19.11 & 18.83 & 14.78 & 13.15 & 7.57 & 8.16 & 15.86 & 18.77 \\
\hline $\mathbf{4}$ & 17.83 & 18.72 & 21.17 & 23.37 & 6.36 & 7.31 & 29.38 & 27.31 \\
\hline $\mathbf{5}$ & 18.67 & 18.61 & 27.36 & 26.09 & 5.69 & 6.84 & 36.79 & 31.90 \\
\hline S.Em $\mathbf{\pm}$ & 19.28 & 17.89 & 34.21 & 36.77 & 5.24 & 5.62 & 41.79 & 44.06 \\
\hline C. D. at 5\% & 0.70 & 0.36 & 0.83 & 1.05 & 0.10 & 0.07 & - & - \\
\hline C.V. (\%) & NS & NS & 2.62 & 3.31 & 0.30 & 0.21 & - & - \\
\hline
\end{tabular}


Table.2 Economics analysis of $M$. vitrata management on green gram (2012)

\begin{tabular}{|c|c|c|c|c|c|c|c|c|c|}
\hline \multirow{2}{*}{$\begin{array}{c}\text { No. of } \\
\text { larva/ } \\
\text { meter } \\
\text { row }\end{array}$} & \multirow{2}{*}{\multicolumn{2}{|c|}{$\begin{array}{c}\text { Grain } \\
\text { Yield } \\
\text { (kg/ha) }\end{array}$}} & \multirow{2}{*}{$\begin{array}{c}\text { Yield loss } \\
\text { (Kg/ha) }\end{array}$} & \multirow{2}{*}{$\begin{array}{l}\text { Value of } \\
\text { yield loss } \\
\text { (Rs./ha) }\end{array}$} & \multirow{2}{*}{$\begin{array}{l}\text { Value of } \\
\text { yield } \\
\text { loss Saved } \\
\text { (Rs./ha) }\end{array}$} & \multicolumn{3}{|c|}{ Cost of application (Rs./ha) } & \multirow[t]{2}{*}{ BCR } \\
\hline & & & & & & Insecticide & $\begin{array}{l}\text { Labour } \\
\text { charge }\end{array}$ & Total & \\
\hline \multicolumn{10}{|c|}{ Year - 2012} \\
\hline $\mathbf{0}$ & & 1125.00 & - & - & - & - & - & - & - \\
\hline 1 & & 1000.00 & 125.00 & 7500.00 & 6000 & 2820 & 1200 & 4020 & $1: 1.49$ \\
\hline 2 & & 946.25 & 178.75 & 10725.50 & 8580 & 2820 & 1200 & 4020 & $1: 2.13$ \\
\hline 3 & & 795.00 & 330.00 & 19800.00 & 15840 & 2820 & 1200 & 4020 & $1: 3.94$ \\
\hline 4 & & 711.25 & 413.75 & 24825.50 & 19860 & 2820 & 1200 & 4020 & $1: 4.94$ \\
\hline 5 & & 655.00 & 470.00 & 28200.00 & 22560 & 2820 & 1200 & 4020 & $1: 5.61$ \\
\hline \multicolumn{10}{|c|}{ Year - 2013} \\
\hline $\mathbf{0}$ & & 1256.25 & - & - & - & - & - & - & - \\
\hline 1 & & 1113.61 & 142.64 & 8558.33 & 6846.67 & 2820 & 1200 & 4020 & $1: 1.70$ \\
\hline 2 & & 1020.56 & 235.69 & 14141.67 & 11313.33 & 2820 & 1200 & 4020 & $1: 2.81$ \\
\hline 3 & & 913.19 & 343.06 & 20583.33 & 16466.67 & 2820 & 1200 & 4020 & $1: 4.10$ \\
\hline 4 & & 855.56 & 400.69 & 24041.67 & 19233.33 & 2820 & 1200 & 4020 & $1: 4.78$ \\
\hline 5 & & 702.78 & 553.47 & 33208.33 & 26566.67 & 2820 & 1200 & 4020 & $1: 6.61$ \\
\hline Note: & \multicolumn{9}{|c|}{ 1. Price of green gram grain: Rs.60 per kilogram } \\
\hline & \multicolumn{9}{|c|}{ 2. Emamectin Benzoate $5 \mathrm{WG}$ (3 gram per 10 liter of water) $=$ Rs. 940 per 100 gram } \\
\hline & \multicolumn{9}{|c|}{ 3. For one spray per hector 500 litre solution required and 2 sprays needed during the cropping season } \\
\hline & \multicolumn{9}{|c|}{ 4. Labour charges @ Rs. 200/- per spray x 3 labour= Rs. 600/ha/spray } \\
\hline
\end{tabular}

Fig.1 Relationship between $M$. vitrata larval density and BCR in green gram
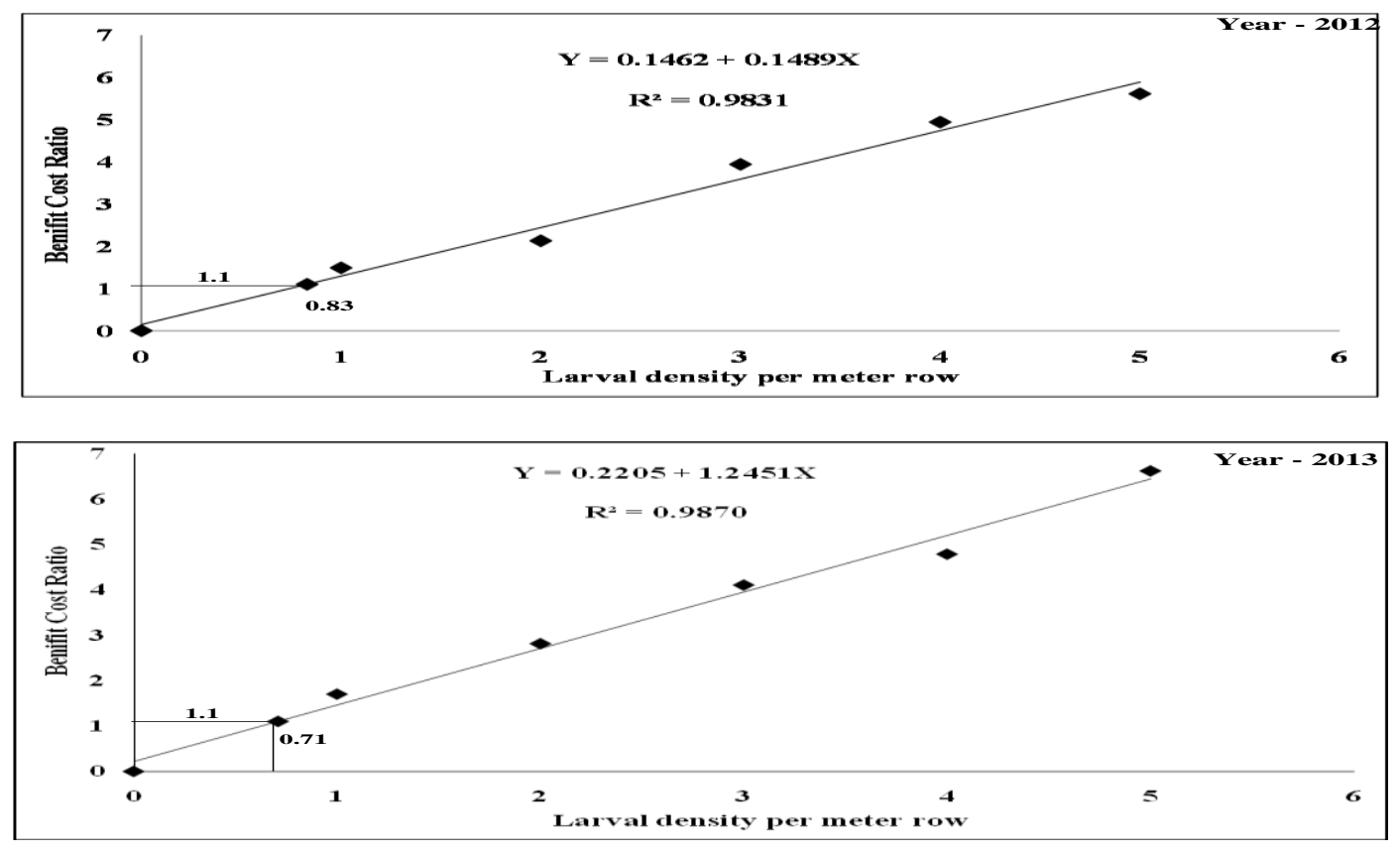


\section{Economic Threshold Level of $M$. vitrata}

Economic threshold level indicated the population density at which control measures should be initiated in order to prevent the population to reaching economic injury level. According to Pedigo (1991), we may choose to set ETL conservatively below EIL, say at 75 per cent of EIL. In present study, economic threshold values were determined from economic injury level and those were found 0.62 and 0.53 larva per meter row during the year 2012 and 2013, respectively. Therefore, on the basis of means of two years the economic threshold level of $M$. vitrata was 0.58 larva per meter row in green gram. Similarly, Zahid et al., (2008) illustrated that ETL value of $M$. vitrata was 0.81 larvaper meter row in green gram.

Overall, investigation of Economic Injury Level (EIL) of M. vitrata was determined as 0.83 and 0.71 larva per meter row, while Economic Threshold Level (ETL) were found 0.62 and 0.53 larva per meter row during first and second year, respectively. On the basis of mean of two years the EIL and ETL values of M. vitrata were 0.77 and 0.58 larva per meter row (i.e. ETL $\approx 1$ larva/2-meter row) in green gram, respectively.

\section{References}

Anonymous. 2015. https://iipr.icar.gov.in/ pdf/7.3_270615.pdf.
Bindra, O. S. 1968. A note on the study of varietal resistance in pulses to different insect pests. In "Second Annual Workshop on Pulse Crops". April 1-3, IARI, New Delhi, pp. 25-31.

Farrington, J. 1977. Economic threshold of insect pest population in present agriculture: A question of applicability. Pest Articles and News Summaries, 23(2): $143-148$.

King, E. G., R. J. Coleman. 1989. Potential for biological control of Heliothis species. Annual Review of Entomology, 34: 53-75.

Pedigo, L. P. 1991. Entomology and Pest Management. MacMillan Publishing Company, New York, pp. 107-119.

Rahman, M. M. 1998. Pest complex of flower and pods of pegionpea and their control through insecticide application. Bangladesh Journal of Scientific Research, 7(1): 27 - 32.

Torres-Vila L.M., M.C. Rodr-Molina, E.Palo, P. Del Estal, A. Lacasa, 2000. El complejo parasitario larvario de Helicoverpa armigera Hubner sobretomate en lasVegas del Guadiana (Extremadura). Boletin de Sanidad Vegetal Plagas, 26: 323-333.

Zahid, M. A., M. M. Islam and M. R. Begum. 2008. Determination of Economic Injury Levels of Maruca vitrata in Mungbean. Journal of Agriculture and Rural Development, 6 (1\&2): 91 - 97.

\section{How to cite this article:}

Patel, H. C., P. K. Borad and Patel, N. B. 2020. Determination of Economic Injury and Threshold Level of Maruca vitrata (Geyer) in Green Gram. Int.J.Curr.Microbiol.App.Sci. 9(09): 3211-3215. doi: https://doi.org/10.20546/ijcmas.2020.909.397. 